\title{
Student Responses to Online Learning of Indonesian Language Subjects Based on LMS Moodle
}

\author{
Vitria Indriyani Setyaningsih*, Laili Etika Rahmawati \\ Fakultas Keguruan Ilmu Pendidikan, Universitas Muhammadiyah Surakarta \\ Jl. A. Yani Tromol Pos 1 Pabelan, Kartasura, Jawa Tengah, Indonesia \\ *Corresponding Author. e-mail: a310170167@student.ums.ac.id
}

\begin{abstract}
This study aims to describe students' responses to online learning of Indonesian language subjects based on Moodle LMS at SMP Negeri 17 Surakarta. The research approach used is descriptive qualitative research. The subject and object of the study focused on seventh grade students of SMP Negeri 17 Surakarta and Indonesian language teachers. The data collection technique in this study was through interview techniques by distributing questionnaires through Google Forms and literature studies. Data analysis techniques used interactive analysis techniques consisting of data reduction, data presentation, and drawing conclusions. The validity of the data was tested using data triangulation techniques and data sources. The results of this study indicate that the students' responses to online learning in Indonesian subjects showed a positive response. The questionnaire shows that students feel happy in online learning using the LMS Moodle for Indonesian subjects. The delivery of the subject matter is very easy to understand because the teacher uses animated videos and video teaching materials. The obstacles experienced during the learning process were handled well by the school's IT team and subject teachers who were very responsive.
\end{abstract}

Keywords: student responses, online learning, LMS Moodle

\section{Respon Siswa terhadap Pembelajaran Daring Mata Pelajaran Bahasa Indonesia Berbasis LMS Moodle}

\begin{abstract}
Abstrak
Penelitian ini bertujuan untuk mendeskripsikan respons siswa terhadap pembelajaran daring mata pelajaran Bahasa Indonesia berbasis LMS Moodle di SMP Negeri 17 Surakarta. Metode penelitian dilakukan melalui survey pendapat dari siswa menggunakan google form. subjek dan objek penelitian berfokus terhadap siswa kelas VII SMP Negeri 17 Surakarta dan guru Bahasa Indonesia. Teknik pengumpulan data dalam penelitian ini melalui teknik wawancara dengan menyebarkan kuesioner melalui Google Form dan studi pustaka. Teknik analisis data menggunakan teknik analisis interaktif yang terdiri dari reduksi data, penyajian data, dan penarikan kesimpulan. Uji keabsahan data dilakukan dengan teknik triangulasi data dan sumber data. Hasil penelitian ini yaitu respons siswa terhadap pembelajaran daring mata pelajaran Bahasa Indonesia menunjukkan respons yang positif. Kuesioner menunjukkan, siswa merasa senang dalam pembelajaran daring menggunakan LMS Moodle untuk mata pelajaran Bahasa Indonesia penyampaian materi pelajaran sangat mudah untuk dipahami karena guru menggunakan video animasi dan video bahan ajar. Kendala yang dialami ketika proses pembelajaran pun ditangani dengan baik oleh tim IT sekolah serta guru mata pelajaran yang sangat responsive.
\end{abstract}

Kata Kunci: respon siswa, pembelajaran daring, LMS Moodle

How to Cite: Setyaningsih, V. I. \& Rahmawati, L. E. (2021). Student responses to online learning of Indonesia language subjects based on lms moodle. Jurnal Penelitian Ilmu Pendidikan, 14(2), 171-180. doi: https://doi.org/10.21831/jpipfip.v14i1.40149.

Received 16-04-2021; Received in revised from 19-05-2021; Accepted 14-06-2021

This is an open-access article under the $\underline{\mathrm{CC}-\mathrm{BY}-\mathrm{SA}}$ license. 
Jurnal Penelitian Ilmu Pendidikan, 14 (2), 2021 - 172

Setyaningsih \& Rahmawati

\section{INTRODUCTION}

In 2020, WHO determined that the corona virus outbreak (Covid-19) was an infectious disease. The transmission of the corona virus is so fast, in fact, almost all over the world have confirmed positive cases of Covid-19. The existence of Covid-19 has caused countries in the world to set large-scale social restrictions (PSBB). All activities that allow crowds are avoided so that the spread of this virus can be suppressed. Until finally, many of these activities are carried out at home by utilizing the internet network to connect to each other. This is commonly known as Work from Home (WFH). Likewise, the education system must be done online.

Education is an effort to realize an effective learning process from individuals consciously and planned as a form of educating students in developing their potential (Nurhayati, Nurhasanah, \& Abdullah, 2016). Ideally, education should be able to develop the potential of students so that educational goals are achieved (Purwaningsih \& Herwin, 2020). Along with the times, humans will get information easily through new technology that is growing (Putri \& Dewi, 2020).

In Indonesia, online learning, which is currently set, follows Circular Letter No. 3 of 2020 as one of the government's efforts to reduce crowd levels, including in the teaching and learning process in Indonesia. The existence of the virus causes the face-to-face learning process to be stopped and changed with the implementation of online learning. Below this definition, it shows that e-learning can be used to support online learning during this pandemic. The change in the education system to online learning makes it possible for students not to come directly to school, because with the internet network, teachers and students can connect directly through online. Online learning is a method of learning through online or learning which is carried out by utilizing the internet network (Mustofa, Muhammad, \& Sayekti, 2019). Online learning has many benefits for educators and students. This method allows the learning process to run effectively, online learning has a wide range and high flexibility (Mulyono, 2020). In this study, the online learning response that was studied was about learning Indonesian language. The use of digital technology in online learning also facilitates between teachers and students (Spencer \& Temple, 2021).

Indonesian language subjects are part of the compulsory subjects that must be studied by students. The Indonesian language subject itself is a lesson that requires students to be able to learn the ins and outs of the language, both the use of language itself and language learning (Kurtanto, 2017). However, learning Indonesian language is often considered boring and the material is not challenging. Especially when online learning is conducted as it is now. Therefore, online learning of Indonesian language subjects needs a more creative and innovative learning model so that students have a high interest in learning Indonesian subjects. Every educator must be able to be creative and have good innovations in preparing creative learning models (Kurtanto, 2017). Online learning is effective if it fulfills the essential components of learning, for example the interactive, adaptive, and reflective (Oktavian \& Aldya, 2020). To support online learning, a learning management system (LMS) is currently needed. LMS is software that functions to create and manage online learning (Rahmasari \& Rismiati, 2013). So far, many LMS have provided free services, one of which is Moodle. Moodle comes from the term Modular Object-Oriented Dynamic Learning Environment. Moodle is a learning application program using an object-oriented model (Munir, 2012). Moodle is included in software that is used to create and conduct internet-based training/education (Triluqman \& Sukirman, 2009). Furthermore, Moodle is a learning platform that can be used by educators and students as well as other administrators as a secure integrated system (Fatmawati, 2019). Many facilities are provided by this Moodle LMS, including discussion forums, chats, assignments, quizzes, and surveys.

The selection of LMS for the implementation of online learning must also pay attention to student responses, because in essence the learning process is a communication of material delivery from educators to students as students. Online learning certainly has obstacles or problems in its implementation. Online learning will certainly experience many obstacles in its implementation, several things that are often found, one of which is the internet network in some areas which is unstable, that students certainly feel happy with the online learning system (Padli \& Rusdi, 2020). However, students still encounter problems regarding internet facilities and online learning costs that need to be spent. Seeing this, student responses in online learning really need to be considered so that 
teachers can find out student interest and participation in participating in the online learning process. Therefore, student responses related to online learning are also closely related to student motivation in participating in the learning. Student learning motivation must arise from within each student, both intrinsic and extrinsic motivation (Amna, 2017). The way to see student involvement in carrying out online learning can be seen through student responses or perceptions (Febrilia, Nissa, Pujilestari, \& Setyawati, 2020). In line with this, students' perceptions are the stimulation of the six senses possessed by humans to form an understanding (Anhusadar, 2020).

The rapid development of technology that affects education in Indonesia must also be followed by the readiness of students to accept and use digital technology in the learning process. The importance of digital readiness and skills that must be prossessed by students so that students can experience a more positive online learning experience (Kim, Hong, \& Song, 2019). The learning process requires a positive response from students because student responses are behaviors that result from the inclusion of stimuli given by the teacher to students (Kusmaryono \& Setyawati, 2013). Based on this explanation, the authors conducted this research by obtaining information about how students respond to online learning in Indonesian subjects based on LMS Moodle. Therefore, this study aims to reveal student responses to online learning of Indonesian language subjects based on LMS Moodle.

\section{METHODS}

This type of research is descriptive qualitative research by describing the results of the analysis of the instrument, namely the distribution of questionnaires to class VII students at SMP Negeri 17 Surakarta. The method is carried out by means of an opinion survey using a google form regarding online learning based on LMS Moodle with the subject and object of research focusing on seventh grade students at SMP Negeri 17 Surakarta, Indonesian language teachers, and LMS Moodle used in online learning. Data collection techniques used are the results of questionnaires, observation, and document analysis. Interview technique was conducted to obtain data by interviewing students and teachers as research subjects. The data that has been obtained from the results of the questionnaire is then confirmed against a predetermined sample. To be able to test the validity of the data, the researchers used triangulation techniques. The triangulation technique used is triangulation of data and data sources. The data analysis technique used in this study uses an interactive analysis technique developed by (Miles \& Huberman, 2014: 15-21) with stages, namely data reduction, data presentation and then drawing conclusions.

\section{Result}

\section{RESULT AND DISCUSSION}

The results of this study found several facts derived from the results of the respondent's analysis related to student responses to online learning based on Moodle LMS. The category of student responses to online learning based on Moodle's LMS here is included in the indication of students' feelings in receiving lessons. The responses referred to here are related to the process of students participating in online learning, students' motivation to participate in learning, and the desire to carry out teacher instructions related to the tasks given. At SMP Negeri 17 Surakarta, online learning is carried out entirely on the Moodle LMS. Student responses in online learning of Indonesian language subjects based on Moodle LMS showed positive results. These results were obtained through the distribution of a questionnaire in the form of a google form to 211 respondents, namely class VII students at SMP Negeri 17 Surakarta who took Indonesian language subjects with 6 question indicators.

\section{Interest in Online Learning}

The results of distributing questionnaires to 211 class VII students of SMP N 17 Surakarta, obtained responses that came in as many as 135 respondents and are shown in the following diagram. 
The level of student interest in online learning during the pandemic with the highest number of students choosing the quite pleasant answer category was 102 students with a percentage of $76 \%$, while students chose the happy answer category as many as 33 with a percentage of $24 \%$. Figure 1 is an explanation of student responses to interest in online learning.

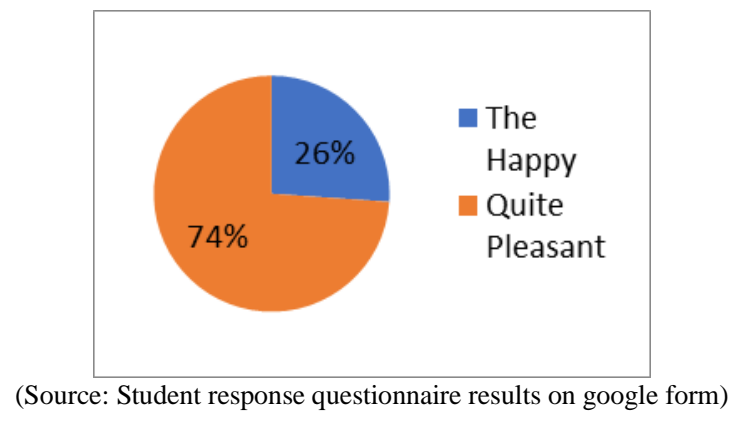

Figure 1. The level of student interest in online learning

From the Figure 1, students chose the most answers, namely the category of answers that were quite happy. The temporary assumption that students choose the answer is due or the transition from face-to-face learning to online learning. In addition, the difficulties that students often face when learning online, such as internet network constraints also underlie students choosing quite happy answers rather than very happy answers. Another thing that underlies this answer is that it is also possible that online learning allows students to study at home without having to come to school, meaning that students have enough space when learning is done online. Especially during this pandemic, online learning allows students to avoid the dangers of the coronavirus as an effort to support the regulations that have been made by the government.

\section{Students' Response to Online Learning Based on LMS Moodle}

The categories of student responses to online learning based on LMS Moodle here include an indication of students' feelings in receiving the lessons. In addition to seeing student responses to online learning, it is also necessary to know about student responses to online learning using the LMS Moodle because it is directly related to student learning activities in the LMS Moodle. The response referred to here is related to the learning process that students go through, students' motivation to take part in learning, and the desire to carry out the teacher's instructions regarding the given task. The results of the respondents who entered as many as 135 students. The highest number was found in students who chose the quite pleasant answer category, namely 61 students with a percentage of $45.2 \%$, while students who chose pleasant answers were 54 students with a percentage of $40 \%$. The lowest respondents were students who chose the very happy answer category, namely 23 students with a percentage of $17 \%$. Looking at the results of the questionnaire on online learning on Indonesian language subjects based on the LMS Moodle during the covid-19 pandemic through the google form, as many as 135 respondents showed a positive response category. The data is shown through the following Figure 2.

After knowing the questionnaire data on student responses to online learning, then students who choose the category of answers that are quite fun are required to provide reasons or brief descriptions of their feelings towards online learning using the LMS Moodle. Most of the answers given by students as respondents said that LMS Moodle was considered very fun and quite helpful in the online learning process. Here are some brief descriptions of students towards online learning in Indonesian language subjects based on LMS Moodle quoted from the results of a questionnaire made via google form; student initials (GA) "The assignments and materials given through LMS Moodle are quite fun and easy to follow, especially in the Indonesian language course", student initials (JA) "LMS Moodle is very helpful in working on Indonesian subject matter and other materials", and student initials (NPP) "The teacher helped me enough in the learning process when using the online 
model and it was easier by using the LMS Moodle ". Those show that students are very interested in online learning because it reveals the many benefits that can be obtained when learning is done online

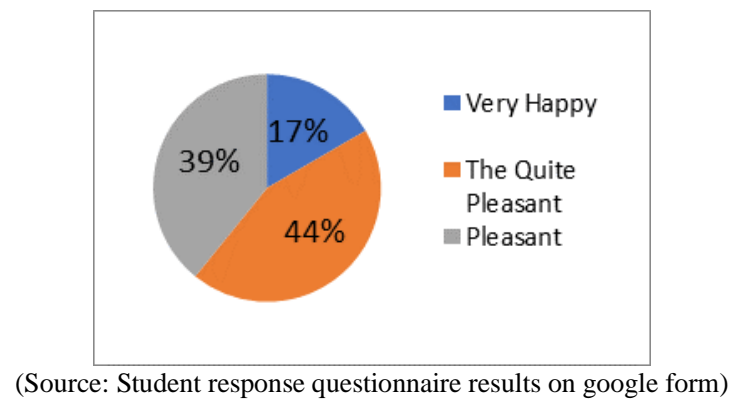

Figure 2. Students data response to online learning based on LMS Moodle

\section{Difficulty Level of Student in Accessing LMS Moodle}

By paying attention to Figure 3, from 135 student respondents, the highest answer of students who chose the "sometimes" category was 62 people with a percentage of $51 \%$, which felt that they had difficulty accessing Moodle during the learning process. Then the students who chose the "no" answer category were 48 students with a percentage of $40 \%$. Therefore, the assumption that students choose the answer "quite fun" in participating in the Indonesian language learning process based on LMS Moodle compared to the "very pleasant" answer is based on the level of difficulty that is often experienced when accessing the LMS Moodle.

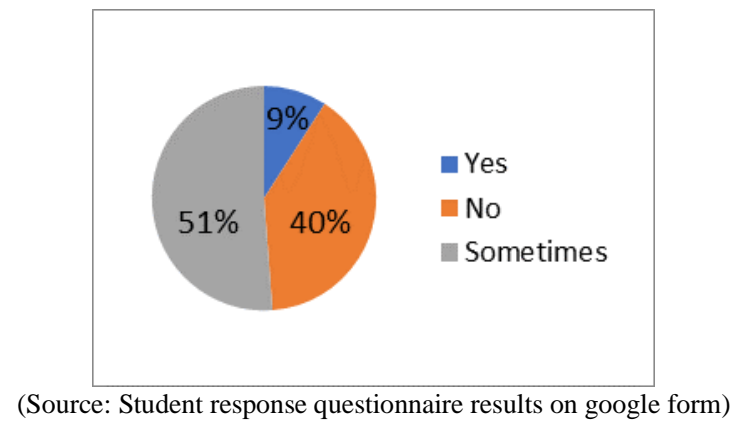

Figure 3. Data on student difficulties in accessing LMS Moodle

This is also shown through questionnaire data describing the difficulties experienced by students when accessing the LMS Moodle. This data is supported by direct observations at SMP Negeri 17 Surakarta, that there are still many students who come to school and ask the IT team because they have difficulty accessing the LMS Moodle and students who communicate with the subject teacher. Some of the reasons that underlie students having difficulty accessing the LMS Moodle are difficult to log into the LMS Moodle, servers that often experience errors, and inadequate signal conditions. All these obstacles can be handled well by the IT team of SMP Negeri 17 Surakarta

\section{Delivering of Indonesia Language Materials Using LMS Moodle}

The results of the questionnaire obtained showed a number that was quite significant. The total number of 135 respondents who entered, the highest number in the category of "understand enough" answers to the question "Is the delivery of Indonesian language subject matter through the LMS Moodle easy to understand?" namely as many as 71 students as respondents with a percentage of 52.26\%. The smallest number of "understand" answer choices is 40 students with a percentage of $29.6 \%$ and the answer choices "very understand" are 24 student respondents with a percentage of $17.8 \%$. This is addressed through the following Figure 4. 


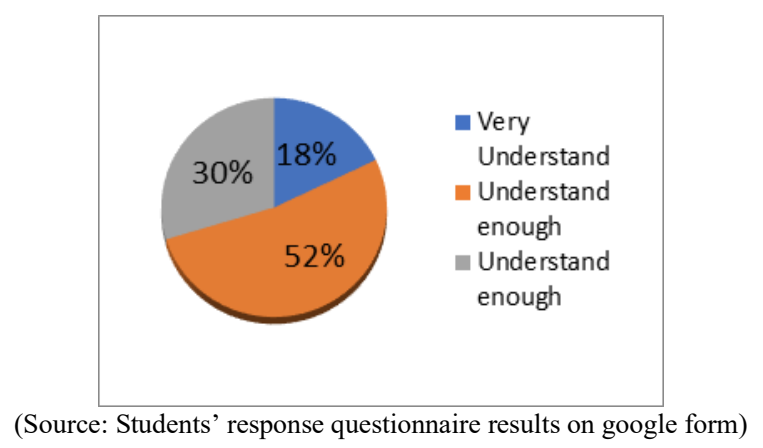

Figure 4. Submission of learning materials using LMS Moodle

The students felt that they fully understood the delivery of Indonesian language learning materials delivered by the teacher. The online learning process for Indonesian Language subjects is delivered by providing videos of teaching materials by the teacher and accompanied by materials exposure. So that it makes students feel quite familiar with the material presented by the teacher which is supported by videos and exposure to material that meets students' learning needs. Giving to the materials also supports students to be able to understand the delivery of material made by the teacher through video teaching material

\section{Delivering Way of Interested Indonesian Lesson Materials}

Looking at the results of the questionnaire obtained from 135 student respondents, the question points regarding "the method of delivering Indonesian language learning materials that are most interested by students" then the highest answer is 80 students with a percentage of $58 \%$ choosing the answer "exposure to the material". While the students who chose the answer "teaching material video" were 46 student respondents with a percentage of $33 \%$, as for the answer category "a combination of video teaching materials and material exposure" as many as 7 student respondents with a percentage of $8 \%$ and student respondents who chose the zoom application as an online learning model as many as 2 student respondents with a percentage of $1 \%$. The data is shown through Figure 5.

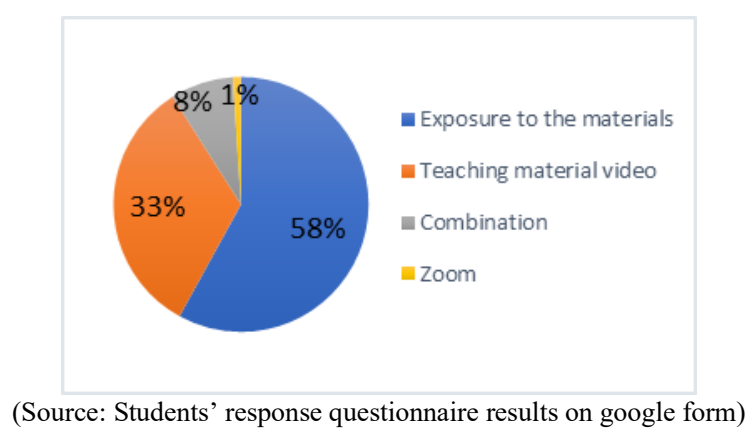

Figure 5. How to submit Indonesian language lesson materials online

From that Figure 5, using video teaching materials allows students to get direct video explanations by the teacher regarding material that may be difficult for students to understand, especially students who can receive material in visual form or students with auditory type, teachers are free to explain learning materials to students through facial expressions or emphasis on certain material in the form of video teaching materials. Not only by using video teaching materials, but material exposure can also be used to support students' ability to capture Indonesian Language subject matter. Material exposure can make it easier for students to take notes and read materials that have been given by the teacher anytime. 
Jurnal Penelitian Ilmu Pendidikan, 14 (2), 2021 - 177

Setyaningsih \& Rahmawati

\section{Discussion}

By looking at the results of student responses to each aspect of the question on the diagram, it shows that the results are good. This shows that students' responses to online learning in Indonesian subjects are in the positive response category. Furthermore, looking at the results of student responses to online learning in Indonesian subjects, the responses were quite good as well, this was indicated by the results of a questionnaire to questions about students' feelings towards online learning based on LMS Moodle and student responses to the delivery of material in Indonesian subjects. by using LMS Moodle students find it quite fun. Students who can be directly involved in the learning process and participate in learning well influence learning outcomes during the learning process. Online learning has many benefits, namely students can obtain information on a more flexible time and place where positive responses depend also on student engagement in online learning (Caliskan, Suzek, \& Ozcan, 2018). Research conducted by Rusman, abdul aziz \& Nasution (2020) revealed that students' negative responses were caused by a lack of enthusiasm for students in participating in online learning, so students were not fully involved in learning. Students will continue to follow online learning even though they experience difficulties, so students will be fully involved in online learning (Mulyana, Rainanto, Astrini, \& Puspitasari, 2020). Evidence that although there are many obstacles in the implementation of learning, there are also several benefits, such as the confidence of students in getting their learning needs through the internet media that is often used. Digital technology is generally used for activities such as finding or storing information in the learning process that can be done by students more easily (Yot-Domínguez \& Marcelo, 2017).

Some of the difficulties faced by students when accessing Moodle LMS are common and not serious problems. In addition, the percentage of students as much as $90 \%$ felt that they did not experience significant difficulties when accessing the Moodle LMS. The same thing is also shown in research conducted by Purniawan \& Sumarni (2020) that every obstacle in online learning generally must occur. This is a challenge as well as a problem that must be resolved by the government in terms of maintaining the quality of education to achieve optimal and superior learning objectives. A challenge in education must be solved because it concerns the quality of education in Indonesia (Cahyani, Listiana. \& Larasati, 2020).

Some of the difficulties experienced by students regarding the process of entering the LMS Moodle can also be handled well by the IT team at the school. Students gave a positive response indicated by their motivation to take part in online learning, their interest in participating in Indonesian language learning where the teacher was very responsive when providing information while learning was in progress, and the way the material was delivered by the teacher was fun. Research conducted by Alfina (2020) shows the results that the use of LMS helps students improve attitudes and accept learning with new technologies. Some of the benefits that can be felt by students during online learning are that they do not feel bored because of the variations made by the teacher during the learning process. Previous research stated the same thing that online learning makes it possible not to feel bored, the online learning system makes learning more fun and feels more effective (Sobron, Bayu, \& Meidawati, 2019). As well as from the results of the questionnaire on the method of delivering the material desired by students, the data shows that students prefer to use the method of giving videos of teaching materials and presentation of material. The material provided by the teacher is very influential on the results of delivering material to students. Teachers should be able to prepare materials as attractive as possible in displaying learning materials, be able to master information technology used as online learning media and be proactive to make students active in participating in online learning (Asmuni, 2020). Accordingly, teachers must be more adaptive to create more flexible, interesting, and interactive learning because online learning must be able to provide positive feedback (Oktavian \& Aldya, 2020). Students who have high motivation and interest in learning will continue to give a positive response to online learning by finding solutions to the obstacles they face. Student responses in online learning that show a positive category are shown by the attitude of students feeling happy to learn with the online system, although there are still some obstacles that must be faced by these students and immediately corrected by the teacher as an evaluation material (Padli \& Rusdi, 2020). Use of LMS gives an influence on increased learning activities because LMS has a variety of menus (features) that are more complete (Widiyono, 2021). 
Based on the results of interviews with Indonesian teachers, they stated that in the transition system from conventional learning to online learning using the LMS Moodle application, students felt less enthusiastic in participating in online learning. This is because students need adaptation first, until finally students feel comfortable in online learning using the LMS Moodle. The emergence of difficulties or obstacles in the online learning process is certain to be encountered, but online learning must still be carried out because it considers the importance of maintaining social distance during this pandemic (Ali, 2020). Of course, online learning will certainly have a positive impact on both educators and students who can facilitate more efficient and effective learning activities both in terms of place and time of implementation (Ningsih, 2020). Online learning should also be able to create a more effective space for students to be able to actualize themselves in every learning activity. It is necessary to pay attention that educational institutions must be able to create easy, flexible access and without being limited by space and time so that the online learning process can run effectively (Imania \& Bariah, 2019). The selection of the right online learning media also makes teachers able to provide interesting content and more active communication so that online learning is more interactive $(\mathrm{Yu}, 2021)$. In line with this, active communication from teachers in fostering more active learning to connect with students, be able to achieve academic success, self-satisfaction and increase student learning motivation (Cho, Melloch, \& Levesque-Bristol, 2021).

\section{CONCLUSION}

The results showed that the level of student response to online learning in Indonesian subjects based on LMS Moodle showed a positive category. The positive response of students is also shown through the descriptive data that has been revealed by students that online learning using LMS Moodle is fun and easy to understand, especially in Indonesian subjects. There are several obstacles experienced by students such as internet network problems and technical problems. However, this is always well communicated to the teachers and the IT team who are ready to handle and assist the online learning process. So that these obstacles can be overcome properly by the school. These obstacles can be overcome by improving the quality of teachers' resources in using information technology and providing assistance to students during online learning.

\section{REFERENCES}

Alfina, O. (2020). Penerapan lms-google classroom dalam pembelajaran daring selama pandemi covid-19. Majalah Ilmiah Methoda, 10(4), 38-46.

Ali, W. (2020). Online and remote learning in higher education institutes: A necessity in light of covid-19 pandemic. Canadian Center of Science and Education, 10(3), 16-25. https://doi.org/10.5539/hes.v10n3p16.

Amna, E. (2017). Kedudukan motivasi siswa dalam pembelajaran. Lantanida Journal, 5(2), 172-182.

Anhusadar, L. O. (2020). Persepsi mahasiswa piaud terhadap kuliah online di masa pandemi. Journal of Islamic Early Childhood Education, 3(1), 44-58.

Asmuni. (2020). Problematika pembelajaran daring di masa pandemi covid-19 dan solusi pemecahannya. Jurnal Paedagogy, 7(4), 281-288.

Cahyani, A., Listiana, I. D., \& Larasati, S. P. D. (2020). Motivasi belajar siswa sma pada daring di masa pandemi covid-19. IQ (Ilmu Al-Qur'an): Jurnal Pendidikan Islam, 3(01), 123-140. https://doi.org/10.37542/iq.v3i01.57.

Caliskan, S., Suzek, S., \& Ozcan, D. (2018). Determining student satisfaction in distance education courses. Procedia Computer Science, 120, 529-538. https://doi.org/10.1016/j.procs.2017.11.275.

Cho, H. J., Melloch, M. R., \& Levesque-Bristol, C. (2021). Enhanced student perceptions of learning and performance using concept-point-recovery teaching sessions: A mixed-method approach. International Journal of STEM Education, 8(1), 1-17. https://doi.org/10.1186/s40594-02100276-1. 
Fatmawati, S. (2019). Efektivitas forum diskusi pada e-learning berbasis moodle untuk meningkatkan partisipasi belajar. Refleksi Educate: Jurnal Ilmiah Kependidikan, 9(2), 211-216. http://jurnal.umk.ac.id/index.php/RE.

Febrilia, B. R. A., Nissa, I. C., Pujilestari, \& Setyawati, D. U. (2020). Analisis keterlibatan dan respon mahasiswa dalam pembelajaran daring menggunakan google classroom di masa pandemi covid-19. FIBONACCI: Jurnal Pendidikan Matematika dan Matematika, 6(2), 175-184.

Imania, K. A., \& Bariah, S. K. (2019). Rancangan pengembangan instrumen penilaian pembelajaran berbasis daring. Jurnal Petik, 5(1), 31-47. https://doi.org/10.31980/jpetik.v5i1.445.

Kim, H. J., Hong, A. J., \& Song, H. D. (2019). The roles of academic engagement and digital readiness in students' achievements in university e-learning environments. International Journal of Educational Technology in Higher Education, 16(1), 1-18. https://doi.org/10.1186/s41239-019-0152-3.

Kurtanto, E. (2017). Keefektifan model pembelajaran daring dalam perkuliahan bahasa Indonesia di perguruan tinggi. Journal Indonesian Language Education and Literature, 3(1), 150. http://www.syekhnurjati.ac.id/jurnal/index.php/jeill/\%0APEMBELAJARAN.

Kusmaryono, H., \& Setyawati, R. (2013). Penerapan inquiry based learning untuk mengetahui respon belajar siswa pada materi konsep dan pengelolaan koperasi. Dinamika Pendidikan, 8(2), 133145. https://doi.org/10.15294/dp.v8i2.3369.

Mulyana, M., Rainanto, B. H., Astrini, D., \& Puspitasari, R. (2020). Persepsi mahasiswa atas penggunaan aplikasi perkuliahan daring saat wabah covid-19. JAS-PT (Jurnal Analisis Sistem Pendidikan Tinggi Indonesia), 4(1), 47. https://doi.org/10.36339/jaspt.v4i1.301.

Mulyono, w. D. (2020). Respons mahasiswa terhadap pembelajaran daring pada masa pandemi covid19. Jurnal STEAM, 2(1), 23-30.

Mustofa, M., Muhammad, C., \& Sayekti, L. (2019). Formulasi model perkuliahan daring sebagai upaya menekan disparitas kualitas perguruan tinggi. Walisongo Journal of Information Technology, 1(2), 151-160.

Munir. (2012). Kurikulum berbasis teknologi informasi dan komunikasi. Bandung: Alfabeta.

Ningsih, S. (2020). Persepsi mahasiswa terhadap pembelajaran daring pada masa pandemi covid-19. JINOTEP (Jurnal Inovasi dan Teknologi Pembelajaran): Kajian dan Riset dalam Teknologi Pembelajaran, 7(2), 124-132. https://doi.org/10.17977/um031v7i22020p124.

Nurhayati, N., Nurhasanah, N., \& Abdullah, D. (2016). Dinamika motivasi belajar pada siswa mandiri di smpn 10 Banda Aceh. Jurnal IImiah Mahasiswa Bimbingan Konseling, 4(4), 73-79.

Oktavian, R., \& Aldya, R. F. (2020). Efektivitas pembelajaran daring terintegrasi di era pendidikan 4.0. Didaktis: Jurnal Pendidikan dan Ilmu Pengetahuan, 20(2), 129-135. https://doi.org/10.30651/didaktis.v20i2.4763.

Padli, F., \& Rusdi, R. (2020). Respons siswa dalam pembelajaran online selama pandemi. Social Landscape Journal,1(3), 1-7.

Purniawan, \& Sumarni, W. (2020). Analisis respon siswa pada pembelajaran daring di masa pandemi covid 19. Seminar Nasional Pascasarjana UNNES, 784-789.

Purwaningsih, A. Y., \& Herwin, H. (2020). Pengaruh regulasi diri dan kedisiplinan terhadap kemandirian belajar siswa di sekolah dasar. Jurnal Penelitian Ilmu Pendidikan, 13(1), 22-30. https://doi.org/10.21831/jpipfip.v13i1.29662.

Putri, L. A., \& Dewi, P. S. (2020). Media pembelajaran menggunakan video atraktif pada materi garis singgung lingkaran. Mathema: Jurnal Pendidikan Matematika, 2(1), 32. https://doi.org/10.33365/jm.v2i1.568.

Putri, L. A., \& Dewi, P. S. (2020). Media pembelajaran menggunakan video atraktif pada materi garis singgung lingkaran. Mathema: Jurnal Pendidikan Matematika, 2(1), 32. https://doi.org/10.33365/jm.v2i1.568.

Rahmasari \& Rismiati. (2013). E-Learning pembelajaran jarak jauh untuk sma. Bandung: Yrama Widya.

Rusman, A, A., \& Nasution, F. (2020). Deskripsi kebahagiaan belajar mahasiswa bki pada masa pandemi covid-19. Jurnal Pendidikan dan Konseling, 12(01), 53-59.

Sobron, A. N., Bayu, R., \& Meidawati. (2019). Persepsi siswa dalam studi pengaruh daring learning terhadap minat belajar siswa. Jurnal Pendidikan Islam dan Multikulturalisme, 1(2), 30-38. 
Spencer, D., \& Temple, T. (2021). Examining students' online course perceptions and comparing student performance outcomes in online and face-to-face classrooms. Online Learning Journal, 25(2), 233-261.

Triluqman, H., \& Sukirman. (2009). Pengembangan sistem pembelajaran online berbasis moodle di jurusan kurikulum dan teknologi pendidikan universitas negeri Semarang. Lembaran Ilmu Kependidikan, 38(1), 27-34.

Widiyono, A. (2021). Pengaruh penggunaan $1 \mathrm{~ms}$ dan aplikasi telegram terhadap aktivitas belajar. Jurnal Penelitian Ilmu Pendidikan, 14(1), 91-101.

Yot-Domínguez, C., \& Marcelo, C. (2017). University students' self-regulated learning using digital technologies. International Journal of Educational Technology in Higher Education, 14(1), 1-18. https://doi.org/10.1186/s41239-017-0076-8.

$\mathrm{Yu}, \mathrm{Z}$. (2021). The effects of gender, educational level, and personality on online learning outcomes during the covid-19 pandemic. International Journal of Educational Technology in Higher Education, 18(1), 1-17. https://doi.org/10.1186/s41239-021-00252-3. 